\title{
Aktualisasi Nilai-Nilai Islam Dalam Pembentukan Karakter Mahasiswa Di Pondok Pesantren Nurul Ummah Kotagede Yogyakarta
}

\author{
Rudini $^{1}$ \\ ${ }^{1}$ IAIN Syaikh Abdurrahman Siddik Bangka Belitung
}

\author{
Info Artikel : \\ Diterima 1 April 2020 \\ Direvisi 18 April 2020 \\ Dipublikasikan 27 April 2020
}

\author{
Kata Kunci: \\ Aktualisasi \\ Nilai-Nilai Islam \\ Pembentukan Karakter
}

\author{
Keywords: \\ Actualization \\ Islamic Values \\ Character Building
}

\begin{abstract}
ABSTRAK
Penelitian ini bertujuan untuk mendeskrepsikan secara kritis tentang Pembentukan Karakter Mahasiswa di Pondok Pesantren Nurul Ummah Kotagede Yogyakarta guna mencari jawaban atas permasalahan tentang: bagaiman proses pengaktualisasian nilai-nilai Islam dalam pembentukan karakter mahasiswa di Pondok Pesantren Nurul Ummah Kotagede Yogyakarta. Bagaimana efektivitas pembentukan karakter mahasiswa di Pondok Pesantren Nurul Ummah Kotagede Yogyakarta. Penelitian ini merupakan penelitian lapangan (field research) dan menggunakan pendekatan kualitatif. Pendekatan dalam penelitian ini menggunakan pendekatan sosioantropologis. Hasil penelitian menunjukan bahwa dalam proses pembentukan karakter mahsiswa di pondok pesantren Nurul Ummah Kotagede Yogyakarta terlihat dalam proses perencanaan dan pelaksanaanya. Secara pelaksanaanya, Jenjang pendidikan bagi mahasiswa terbagi menjadi tiga tingkatan yakni awwaliyah, wustha, dan 'ulya. Pengaktualisasian nilai-nilai Islam di pondok pesantren Nurul Ummah di bagi dalam bebrapa program yang meliputi: program harian, program mingguan, program bulanan, dan program tahunan. Nilai-nilai Islam yang diaktualisasikan adalah nilai ilahiyah yang meliputi: nilai ubbudiyah dan nilai ketauhidan. Sedangkan nilai yng bersifat insaniyah meliputi: nilai kedisiplinan, nilai kesederhanaan, nilai kejujuran, nilai musyawarah. Kemudian proses pengaktualisasiannya diterapkan dalam kegiatan pembelajaran dan kegiatan sehari-hari.
\end{abstract}

\begin{abstract}
This study aims to critically describe the formation of student character at the Nurul Ummah Islamic Boarding School in Yogyakarta to find answers to the problem of how the actualization process of Islamic values in the creation of student characters in the Islamic Boarding School Nurul Ummah Yogyakarta. How is the effectiveness of the formation of student character in the Islamic Boarding School Nurul Ummah Kotagede Yogyakarta. This research is field research and uses a qualitative approach. The approach in this study uses a socio-anthropological approach. The results of the research show that in the process of forming the character of students in the boarding school Nurul Ummah Kotagede Yogyakarta seen in the planning and implementation process. In practice, the level of education for students divided into three levels, namely awwaliyah, wustha, and 'ulya. The actualization of Islamic values in the Nurul Ummah Islamic boarding school divided into several programs, which include: daily programs, weekly programs, monthly programs, and annual programs. The actualized Islamic values are spiritual values, which include: ubbudiyah values and monotheism values. Whereas values insaniyah add: the importance of discipline, the cost of simplicity, the amount of honesty, the value of deliberation. Then the actualization process is applied in learning activities and daily activities.
\end{abstract}

\section{Koresponden:}

Rudini,

Email: Rudinidani20@gmail.com

This is an open access article distributed under the Creative Commons Attribution License, which permits unrestricted use, distribution, and reproduction in any medium, provided the original work is properly cited. (2019 by author.

\section{Pendahuluan}

Bangsa Indonesia telah mengalami krisi ekonomi yang bisa mengakibatkan krisis akhlak. Banyak yang menyatakan bahwa persoalan bangsa tersebut merupakan akibat dari merosotnya moral bangsa dengan mewabahnya korupsi, kolusi dan nepotisme (KKN) diberbagai kehidupan berbangsa dan bernegara. Oleh karena itu, melakukan reformasi secara menyeluruh harus meyentuh pada aspek yang berkaitan dengan 
bidang akhlak. Faktor utama yang menyebabkan tumbuh suburnya praktek-praktek korupsi, kolusi, dan nepotisme masyarakat Indonesia adalah akhlak yang buruk serta rendahnya kualitas keimanan dan ketaqwaan. Bahkan tidak menutup kemungkinan berkembangnya kecendrungan sadisme, kriminalitas, serta merebaknya pornografi dan pornoaksi di tengah-tengah masyarakat (Husin, 2005).

Berkenaan dengan itu, maka upaya menegakkan akhlak mulia bangsa merupakan suatu keharusan mutlak. Akhlak yang mulia akan menjadi pilar utama untuk tumbuh dan berkembangnya peradaban suatu bangsa. Kemampuan suatu bangsa untuk bertahan ditentukan oleh sejauhmana rakyat dari bangsa tersebut menjunjung tinggi nilai-nilai akhlak dan moral. Semakin baik akhlak dan moral suatu bangsa, semakin baik pula bangsa yang bersangkutan atau sebaliknya. Tidak berlebihan jika dikatakan bahwa pendidikan akhlak dalam Islam adalah aspek yang tidak dapat dipisahkan dari pendidikan agama. Hal ini disebabkan bahwa sesuatu yang disebut baik barometernya adalah baik dalam pandangan agama dan masyarakat, demikian pula sebaliknya sesuatu yang dianggap buruk barometernya adalah buruk dalam pandangan agama dan masyarakat (Husin, 2005).

Pendidikan merupakan bagian penting dari hidup dan kehidupan manusia, dan sudah semestinya sejalan dengan perkembangan tuntutan masyarakat. Ini berarti bahwa pendidikan adalah sebagai pelestari tata sosial dan tata nilai yang ada dan berkembang dalam masyarakat sekaligus sebagai agen perubahan (Usman, 2010). Dalam konteks kenegaraan, penyelenggaraan pendidikan secara yuridis formal di atur dalam undangundang Sisdiknas nomor 2 tahun 2004. Dalam undang-undang tersebut, pendidikan diartikan sebagai usaha sadar dan terencana untuk mewujudkan suasana belajar dan proses pembelajaran agar peserta didik secara aktif mengembangkan potensi dirinya untuk memiliki kekuatan spiritual keagamaan, pengendalian diri, kepribadian, kecerdasan, akhlak mulia, serta keterampilan yang diperlukan dirinya, masyarakat, bangsa dan Negara (Wiyani, 2013). Sementara itu dalam Undang-Undang Sisdiknas Nomor 20 Tahun 2003 disebutkan bahwa pendidikan nasional berfungsi mengembangkan kemampuan dan membentuk watak serta peradaban bangsa yang bermartabat dalam rangka mencerdaskan kehidupan bangsa, bertujuan untuk berkembangnya potensi peserta didik agar menjadi bangsa yang beriman, dan bertaqwa kepada Tuhan Yang Maha Esa, berakhlak mulia, sehat, berilmu, cakap, kreatif, mandiri, dan menjadi warga Negara yang demokratis serta bertanggung jawab (Wiyani, 2013).

Pendidikan pesantren yang merupakan jenis pendidikan khas Indonesia tidak diragukan lagi selama puluhan tahun bahkan ada yang telah seabad lebih, memberikan andil dan peranannya dalam mencerdaskan kehidupan bangsa. Dalam dekade terakhir jumlah pesantren semakin berkembang dan kini jumlahnya sekitar 16.000 pesantren. Pesantren dengan corak dan ciri khasnya telah berjasa dalam melahirkan lapisan generasi terdidik umat Islam di berbagai pelosok tanah air (Ali, Abdussakir, \& In'am Esha, 2013) .

Secara pedagogis pesantren lebih dikenal lembaga pendidikan Islam, lembaga yang di dalamnya terdapat proses belajar mengajar ilmu agama Islam dan lembaga yang dipergunakan untuk penyebaran agama Islam. Dalam proses belajar mengajar dalam pesantren diajarkan bahwa Islam adalah agama yang mengatur bukan saja amalan-amalan peribadatan, apalagi sekedar hubungan orang dengan tuhannya, melainkan juga perilakunya dalam hubungannya dengan manusia di dunia. Fungsi pesantren dalam hal ini berarti telah banyak berbuat untuk mendidik santri, mengandung makna sebagai usaha untuk membangun atau membentuk pribadi, warga Negara dan bangsa (Mas' ud, Ismail, Huda, \& Kholiq, 2002). Pesantren dengan teologi yang dianutnya hingga kini ditantang untuk menyikapi globalisasi secara kritis dan bijak. Pesantren harus mampu mencari solusi yang benar-benar mencerahkan sehingga pada satu sisi dapat menumbuh kembangkan kaum santri yyang memiliki wawasan luas yang tidak gampang menghadapi modernitas dan sekaligus tidak kehilangan identitas dan jati dirinya, dan pada sisi yang lain dapat mengantarkan masyarakat menjadi komunitas yang menyadari tentangg persoalan yang dihadapi dan mampu mengatasi dengan penuh kemandirian dan keadaban (A'la, 2006).

Terlepas dari hal di atas, perhatian ke arah akademik pendidikan Islam ini tampak masih sangat kurang. Kalangan pesantren sendiri pada umumnya cendrung berlomba memperbarui sistem pendidikannya sejalan dengan politik dan kebijakan pendidikan Islam di Indonesia. Efek langsung dari kecendrungan ini berimplikasi pada degradasi pendidikan pesantren. Dalam banyak kasus pendidikan pesantren di sejajarkan dengan madrasah atau sekolah.

Tradisi akademik pesantren merujuk pada satu sistem pembelajaran yang tuntas yang dapat menampilkan satu sosok lulusan pesantren yang berwawasan luas dan berkepribadian yang matang. Dengan kata lain, tradisi akademik pesantren merupakan elemen dinamis yang menjaga konsistensi nilai melalui 
transmisi pengetahuan secara berkelanjutan dan sekaligus membuka peluang untuk kemungkinan melakukan transformasi nilai itu (Nizar, 2013). Oleh karena itu, pada hakekatnya pendidikan pesantren tidak hanya berusaha membangun dan mewariskan nilai yang akan menjadi penolong dan penuntun umat manusia dalam menjalani kehidupan, tetapi untuk memperbaiki nasib dan peradabannya. Bahkan dapat dikatakan, baik atau buruknya peradaban suatu bangsa ditentukan oleh pendidikan yang dijalani masyarakatnya. Dengan kata lain, misi pendidikan pesantren adalah berupaya untuk memenuhi berbagai tuntutan kualitas generasi bangsa, baik tuntutan budaya, tuntutan sosial, dan tuntutan perkembangan peserta didik.

Salah satu lembaga pendidikan yang tetap menjaga tradisi pesantren dan berkiprah dalam dalam membentuk generasi yang berilmu dan berakhlak mulia adalah pesantren Nurul Ummah Kota Gede Yogyakarta. Di pesantren ini tidak hanya menyediakan program pendidikan ibtidaiyyah, madrasah tsanawiyah, dan madrasah aliyah saja, namun di pesantren ini juga terdapat program pendidikan yang dikhususkan bagi para mahasiswa.

Pada kenyataan di lapangan, usaha-usaha pembinaan akhlak melalui berbagai lembaga pendidikan dan melalui berbagai macam metode terus dikembangkan. Ini menunjukan bahwa akhlak memang perlu di bina, dan pembinaan ini membutuhkan keseriusan. Keadaan pembinaan ini semakin terasa diperlukan terutama pada saat dimana semakin banyak tantangan dan godaan sebagai dampai kemajuan di bidang iptek. Saat ini misalnya orang akan semakin mudah berkomunikasi dengan apa pun yang ada di dunia ini, yang baik atau yang buruk, karena ada alat telekomunikasi. Peristiwa yang baik atau yang buruk dengan mudah dapat dilihat melalui televisi, internet dan sebagainya. Film, buku-buku, tempat-tempat hiburan yang menyuguhkan adegan yang negative sangat banyak. Demikian pula obat-obatan terlarang, minuman keras dan pola hidup matrealistik dan hedonisik semakin mengenjala. Semua ini jelas membutuhkan pembinaan (Nata, 2013). Dalam kaitan ini, maka nilai-nilai akhlak mulia di tanamkan dalam diri seluruh peserta didik melalui pendidikan agama, pembudayaan dan pembiasaan. Pembinaan akhlak (karakter) perlu usaha yang sungguh-sungguh, sehingga nilai-nilai agama khususnya agama Islam dapat dipahami oleh umatnya dan diaplikasikan dalam kehidupan bermasyarakat.

Sebuah pendidikan yang berlandaskan keislaman menjadi wahana untuk mengembangkan pikiran, menata keperibadian, menumbuh kembangkan spiritualitas dan emosional. Dalam mencapai hal tersebut membutuhkan kelengkapan dalam setiap komponen pendidikan salah satunya adalah kepengurusan. Oleh karena itu, peneliti melihat bahwa kepengurusan yang terjadi di pondok pesantren Nurul Ummah sangat sedikit, sedangkan kegiatan kependidikan di pondok pesantren tersebut sangat banyak. Melihat banyaknya santri yang berstatus pelajar dan santri yang berstatus mahasiswa di pondok pesantren tersebut membutuhkan banyak orang yang terlibat dalam kepengurusan agar setiap kegiatan di pondok tersebut dapat berjalan dengan baik, terlebih berkenaan dengan pembentukan pribadi peserta didik.

\section{Metode}

Jenis penelitian yang digunakan adalah penelitian lapangan (field research) yang bersifat kualitatif. Penelitian kualitatif adalah proses penilaian yang menghasilkan data deskriptifberupa kata tertulis atau lisan dari orang dan prilaku yang dapat diamati (Kasiram, 2010). Sedangkan Pendekatan yang digunakan adalah pendekatan sosiologis-antropologis. Dalam hal ini, penulis ikut serta dalam kegiatan di pondok psantren tersebut guna untuk memperoleh informasi secara akurat. Peneliti akan melihat kegiatan-kegiatan yang dilakukan para mahasiswa, melihat hubungan sosial antara para mahasiswa dengan para ustadz, serta melihat hubungan sosial antara sesama mahasiswa yang mukim dan studi di pondok psantren tersebut. Serta melihat psikologis para mahasiswa dalam mengikuti kegiatan di pondok pesantren Nurul Ummah.

\section{Hasil dan Pembahasan}

\section{A. Aktualisasi Nilai-Nilai Islam Dalam Pembentukan Karakter Mahasiswa}

Sistem pendidikan pesantren di dasari, digerakan, dan diarahkan oleh nilai-nilai kehidupan yang bersumber pada ajaran dasar Islam. Ajaran Islam ini menyatu dengan struktur kontekstual atau realitas sosial dalam kehidupan keseharian. Hal inilah yang menjadi konsep pembangunan dan peran lembaga pesantren. Pesantren memenuhi kriteria yang disebut dalam konsep pembangunan yaitu pembangunan kemandirian, kelestarian, mentalitas, kelembagaan dan etika. Pesantren seperti sebuah ruang bebas pendidikan yang mempunyai karakter nilai yaitu nilai keagamaan, sedangkan batas norma yang dimiliki 
yaitu norma masyarakat. Hampir semua sisi pembentukan keperibadian manusia dapat dihubungkan dalam metode pendidikan di pesantren.

Oleh karena itu, banyaknya mahasiswa yang kuliah dan memilih nyantri di pondok pesantren Nurul Ummah untuk menuntut ilmu menunjukan bahwa mahasiswa sebagai sosok yang memang membutuhkan sebuah bimbingan dan pengajaran dalam hal keilmuan maupun kepribadian. Mahasiswamahasiswa ini berasal dari berbagai kampus yang ada di Yogyakarta dan berasal dari berbagai daerah, baik yang berasal dari wilayah Jawa maupun yang berasal dari luar Jawa. Semua program pendidikan yang berbasis agama di pondok ini berada di bawah naungan Madarasah Diniyyah Nurul Ummah (MDNU), demikian halnya dengan pendidikan bagi mahasiswa. Madrasah Diniyyah Nurul Ummah (MDNU) merupakan suatu unit pendidikan yang menangani bidang pendidikan non formal yang lebih menitik beratkan pada kajian-kajian keagamaan.

Berdasarkan dinamika santri (mahasiswa) yang berasal dari berbagai kampus dan daerah serta berbeda-beda kemampuan dengan tingatan kelas masing-masing, Pondok pesantren Nurul Ummah sebagai lembaga pendidikan yang berbasis Islam juga tidak terlepas dari nilai-nilai keislaman. Dari hasil data yang peneliti dapati di lapangan, adapun nilai-nilai Islam yang diterapkan dalam pendidikan bagi mahasiswa tersebut adalah Sebagai berikut:

1. Nilai Yang Bersifat Ilahiyyah

Adapun nilai-nilai Islam yang bersifat Ilahiyyah yang diterapkan di pondok pesantren ini dalam rangka membentuk mahasiswa yang berkarakter rabbaniyyah adalah sebagai berikut:

a. Nilai Ubudiyyah

Pendidikan Islam tidak hanya menekankan kepada aspek ilmu pengetahuan dan akhlak, akan tetapi juga pada aspek peribadatan. Untuk membentuk pribadi santri (mahasiswa) yang religius tidak terlepas pada aspek peribadatan. Oleh karena itu, pentingnya melatih santri (mahasiswa) yang taat beribadah, tidak hanya mengedepankan ilmu pengetahuan. Inilah peran dari nilai-nilai Islam salah satunya membentuk manusia yang religius dalam segala hal.

Penulis menarik kesimpulan dari paparan diatas bahwa, tujuan dari sebuah pendidikan tidak hanya memberikan ilmu pengetahuan kepada peserta didik, akan tetapi juga membentuk manusia yang berakhlak dan bermanfaat bagi manusia lainnnya serta patuh dan taat kepada Allah. Setinggi apa pun sebuah pendidikan adalah bertujuan untuk mendekatkan seseorang kepada Tuhannya.

b. Nilai Ketauhidan

Bagi umat Islam, nilai pokok yang mengarahkan seluruh aktivitasnya adalah tauhid. Nilai tauhid atau Ketuhanan Yang Maha Esa, bukan satu konsep di tengah-tengah berbagai konsep, tetapi ia merupakan satu prinsip lengkap menembus semua dimensi yang mengatur seluruh khazanah fundamental dan akal manusia (Shihab, 2007).

Menanamkan nilai ketauhidan dengan cara menghayati dan mengamalkannya dalam keseharian peserta didik bertujuan untuk membentuk pola dan sikap hidup santri (mahasiswa), sehingga nilai tersebut dapat melahirkan akhlak dan prilaku yang sesuai dengan makna nilai tersebut.

2. Nilai Islam Yang Bersifat Insaniyyah

Adapun nilai-nilai Islam yang bersifat Insaniyyah yang diterapkan dalam pembentukan karakter religius mahasiswa adalah sebagai berikut:

a. Nilai kedisiplinan

Kedisiplinan terbentuk melalui proses dari serangkaian perilaku yang menunjukan nilai-nilai ketaatan, kepatuhan, ketertiban terhadap peraturan yang telah di tetapkan. Banyak peraturan yang terapkan dalam lingkungan pondok pesantren adalah untuk kelangsungan kegiatan dan juga untuk kebaikan semua yang terkait dengan lembaga, bukan untuk membatasi ruang gerak santri. Dengan menerapkan kedisiplinan di pondok pesantren diharapkan para santri (mahasiswa) mempunyai jiwa kedisiplinan yang tinggi dan membiasakan diri dengan disiplinan. 
Kedisiplinan dalam proses pendidikan sangat diperlukan karena bukan hanya untuk menjaga kondisi suasana belajar dan mengajar berjalan dengan lancar, tetapi juga untuk menciptakan pribadi yang kuat bagi setiap santri (mahasiswa). Perlunya sebuah pembiasaan kedisiplinan dalam membentuk kepribadian (karakter) dalam diri santri (mahasiswa) merupakan langkah yang tepat. Suatu hal apabila dilakukan terus menerus akan menjadi sebuah pembiasaan dan lama kelamaan akan menjadi karakter kuat yang tertanam dalam diri peserta didik (mahasiswa).

b. Nilai kesederhanaan

Membentuk pribadi santri (mahasiswa) yang berkarakter penuh dengan kesederhanaan tidaklah mudak seperti mendengar kata-katanya. Terlebih melihat kondisi sekarang yang penuh dengan kemajuan. Santri (mahasiswa) seringkali dalam keseharian mereka di luar podok pesantren mempunyai kehidupan atau mempunyai gaya hidup yang mewah.

Suatu sistem pendidikan, termasuk pesantren memiliki kelemahan dan kelebihan. Oleh karena itu, yang diperlukan adalah melakukan revitalisasi terhadap pesantren agar kelebihan yang dimilikinya dapat dimanfaatkan secara optimal untuk menghasilkan lulusan yang berkualitas baik dalam keilmuan maupun kepribadian.

c. Nilai Musyawarah

Komunikasi adalah proses suatu ide yang dialihkan dari sumber kepada suatu penerima atau lebih, dengan maksud untuk mengubah tingkah laku. Lebih lanjut komunikasi merupakan proses menyortir, memilih dan mengirimkan simbol-simbol sedemikian rupa sehingga membantu pendengar membangkitkan makna atau respons dari pikirannya yang serupa dengan yang dimaksudkan oleh komunikator atau si pemberi pesan.

Bermusyawarah berati berhubungan dengan orang lain dan ada pesan di dalamnya, maka kedua hal ini saling berhubungan dan berkaitan. Komunikasi membantu proses berjalannya suatu musyawarah. Ada sumber, pesan, media, serta penerima pesan yang sudah bersiap juga untuk memberikan umpan balik. Selain itu terdapat gangguan yang dapat mengancam jalannya informasi.

d. Nilai kejujuran

Kejujuran merupakan kualitas manusiawi melalui mana manusia mengomunikasikan diri dan bertindak secara benar (truthfully). Karena itu, kejujuran sesungguhnya berkaitan erat dengan nilai kebenaran, termasuk di dalamnya kemampuan mendengarkan, sebagaimana kemampuan berbicara, serta setiap perilaku yang bisa muncul dari tindakan manusia. Secara sederhana, kejujuran bisa diartikan sebagai sebuah kemampuan untuk mengekpresikan fakta-fakta dan keyakinan pribadi sebaik mungkin sebagaimana adanya. Sikap ini terwujud dalam perilaku, baik jujur terhadap orang lain maupun terhadap diri sendiri (tidak menipu diri), serta sikap jujur terhadap motivasi pribadi maupun kenyataan batin dalam diri seorang individu.

Perencanaan pendidikan dalam membentuk karakter peserta didik harus dilakukan oleh semua komponen yang terlibat di dalamnya, dalam ini yang terlibat sebagai pelaksana kegiatan pendidikan di pondok pesantren Nurul dalam membentuk karakter santri (mahasiswa) adalah: Pimpinan madrasah diniyyah Nurul Ummah, para ustadz, dan para pengurus. hal berikut:

Pelaksanaan kegiatan pendidikan dalam membentuk karakter peserta didik dilakukan pada hal-

1) Program Pengembangan diri

Dalam program pengembangan diri, pelaksanaan pendidikan dalam membentuk karakter peserta didik dilakukan dalam kegiatan sehari-hari sebagai berikut:

a. Kegiatan rutin sekolah

Kegiatan rutin merupakan kegiatan yang dilakukan peserta didik secara terus menerus dan konsisten setiap hari seperti melaksanakan sholat secara berjamaah (Hamid, 2010) .

b. Kegiatan spontan

Kegiatan spontan yakni kegaiatan yang dilakukan secara spontan pada saat itu juga. Kegiatan ini dilakukan ketika guru atau tenaga pendidik mengetahui adanya perbuatan yang kurang baik dari peserta didik yang harus dikoreksi pada saat itu juga. Apabila guru 
mengetahui adanya perilaku dan sikap yang kurang baik maka saat itu juga guru harus melakukan koreksi. Sehingga peserta didik tidak melakukan perbuatan yang tidak baik itu (Hamid, 2010).

2) Pengintegrasian Dalam Pelajaran

Pembentukan karakter peserta didik diintegrasikan dalam setiap pokok bahasan dari setiap mata pelajaran. Setiap pokok bahasan tersebut dicantumkan dalam silabus dan RPP.

Berkenaan dengan hal tersebut, pengaktualisasian nilai-nilai Islam dalam membentuk karakter santri (mahasiswa), dilakukan dalam kegiatan-kegiatan sebagai berikut:

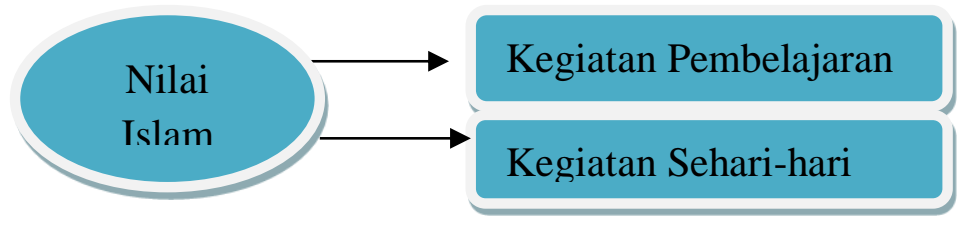

\section{Dalam Kegiatan Pembelajaran}

Pembentukan karakter di dalam proses pembelajaran meliputi pengenalan nilai-nilai, pemberian sarana agar diperolehnya kesadaran akan pentingnya nilai-nilai dan penginternalisasian nilai-nilai dalam tingkan laku peserta didik dalam proses pembelajaran baik yang berlangsung di kelas maupun di luar kelas sangat kompleks. Kegiatan pembelajaran dapat menjadikan peserat didik menguasasi kompetensis secara keseluruhan yakni mengetahui, mengenal, menyadari dan berprilaku sesuai dengan karakter bangsa.

Dalam menanamkan, menumbuhkan, mengembangkan dan memantapkan nilai-nilai kebaikan dalam diri peserta didik harus disesuaikan dengan tingkat kemampuan dan jenjang pendidikan peserta didik. Oleh sebab itu, Dalam penyelenggaraannya pendidikan bagi mahasiswa di pondok pesantren Nurul Ummah ini terbagi menjadi tiga tingkatan:

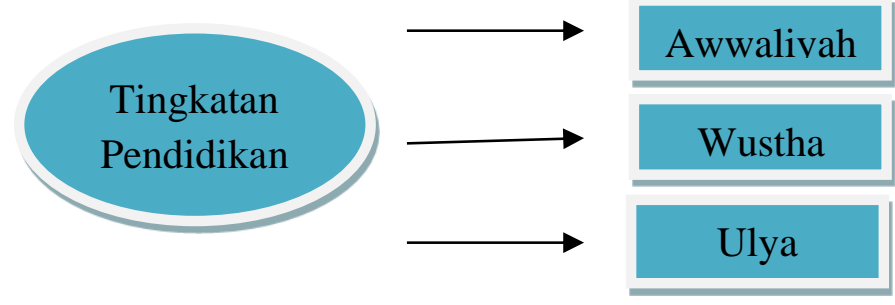

a) Tingkat Awwaliyah (tingkat pertama atau dasar)

Tingkat ini terdiri dari 4 kelas yaitu kelas I, II, III, dan IV. Pada tingkat ini santri (mahasiswa) mempelajari ilmu-ilmu agama yang bersifat dasar, seperti al-Qur'an, hadist, tajwid, fiqih, tauhid, akhlak, tarikh, nahwu, sharaf, qawa'idul I'rab, imla' dan mahfudzad. Dari hasil pengamatan peneliti, adapun metode yang digunakan dalam tingkatan ini adalah hapalan terutama dalam pelajaran nahwu, sharaf, qawa'idul I'rob, mahfuzhat. Selain itu juga menggunakan metode musyawarah seperti pada mata pelajaran fiqih.

Menggunakan sebuah metode dalam proses pembelajaran memang suatu keharusan dalam memberikan pengetahuan sekaligus membentuk karakter peserta didik. Di harapkan dengan menggunakan metode musyawarah dalam kegiatan pembelajaran tersebut dapat membentuk karakter santri (mahasiswa) yang selalu bermusyawarah. Ini merupakan salah satu konsep yang diajarkan oleh Islam.

Penulis menarik kesimpulan, setiap komponen pendidikan pondok pesantren dalam melakukan proses transfer ilmu pengetahuan dan pembinaan kepribadian peserta didik harus benarbenar dengan kesungguhan. pengetahuan membuka jalan pikiran sseorang dalam berpikir, sehingga pikiran ini memberikan kesadaran bagi seseorang tersebut. Kemudian kesadaran inilah yang mempengaruhi dari keperibadian seseorang santri (mahasiswa) dalam bertindak dan mengambil keputusan.

b) Tingkat Wustha (menengah) 
Pada tingkat ini terdiri dari kelas I dan II. Pelajaran pada tingkat ini merupakan pengembangan dari tingkat awwaliyyah yang meliputi: tafsir, ulumul qur'an, hadis, ulumul hadist, ushul ad da'wah, ushul fiqih, qawaid al-fiqh. ${ }^{1}$ Metode yang digunakan pada tingkatan ini semakin bervariasi diantaranya dengan metode presentasi. Agar meningkatkan daya nalar dan mengembangkan wawasan santri (mahasiswa), dalam hal ini mahasiwa diperlakukan sebagaimana layaknya mahasiswa dalam pembelajaran di kampus, sehingga mahasiswa terkesan seperti melakukan perkuliahan.

Penggunaan metode presentasi dalam tingkat wustha ini diharapkan dapat membentuk karakter kemandirian pada diri santri (mahasiswa). Dengan mempersentasikan suatu materi, santri (mahasiswa) berusaha untuk menjelaskan dan memahami sekaligus memberikan pemahaman kepada para pendengarnya. Sehingga apa yang disampaikan merupakan hasil pikiran atau daya nalar santri (mahasiswa) itu sendiri.

c) Tingkat Ulya (atas)

Pada tingkatan ini terdiri dari kelas I dan II. Pengembangan pelajaran pada tingkat ini dengan penambahan pelajaran yang meliputi: balaghah, manti', tasawuf, tarikh tasyri', dan faraid. Sebagai tugas akhir, khusus santri (mahasiswa) kelas II ulya diwajibkan menyusun risalah (sebuah penelitian seperti halnya skripsi), namun kebanyakan penelitian yang dilakukan oleh santri (mahasiswa) lebih cendrung bersifat kualitatif (studi pustaka).

Pendidikan diniyyah atau pendidikan agama merupakan ruh pondok pesantren. Oleh karena itu, dalam menentukan kelas-kelas tersebut setiap santri baru akan di tes berkenaan sejauh mana kemampuan mereka terhadap ilmu-ilmu keislaman, sehingga dengan adanya tes ini maka dapat ditentukan santri tersebut ditetapkan kelasnya.

Berkenaan dengan nilai-nilai Islam yang diaktualisasikan dalam kegiatan pembelajaran adalah nilai ketauhidan, nilai musyawarah, nilai kedisiplinan. Adapun prosesnya sebagai berikut:

a. nilai ketauhidan

Diaktualisasikannya nilai ketauhidan dalam kegiatan pembelajaran bagi mahasiswa bertujuan sebagai salah satu bentuk taqorrub ilallah (mendekatkan diri kepada Allah) dan sebagai bentuk pemuliaan terhadap ilmu pengetahuan. Dalam prosesnya nilai ketauhidan ini dilakukan sebelum kegiatan belajar megajar berlangsung. Hal tersebut dilakukan dengan cara: setiap santri (mahasiswa) berkumpul di depan kelas masing-masing, kemudian membacakan al asma ul husna secara bersama-sama yang di pimpin oleh satu orang santri (mahasiswa), setelah pembacaan al asma ul husna selesai dilanjutkan dengan membaca doa khusus, setelah selesai doa barulah para santri (mahasiswa) masuk ke dalam kelas.

Tujuan dari membaca al-asma ul husna dan doa di depan kelas sebelum kegiatan belajar berlangsung, diharapkan dapat membentuk karakter religius santri (mahasiswa). Santri (mahasiswa) tidak hanya hafal nama-nama Allah, akan tetapi diharapkan seiring seringnya pengulangan dan pengucapan nama-nama Allah tersebut maka santri akan berkarakter seperti itu. Sebagai contoh dalam al-asma ul husma terdapat nama Allah yakni ar-rahman yang berati maha pengasih dan ar-rahim yang berarti maha penyayang. Diharapkan santri (mahasiswa) juga berkarakter kasih sayang terhadap dirinya, orang lain dan lingkungan sekitarnya.

b. Nilai kedisiplinan

Pengaktualisasian nilai kedisplinan di dalam proses belajar mengajar ini dilakukan dengan cara: diberlakukannya peraturan bahwa semua santri (mahasiswa) sebelum pembelajaran di mulai sudah berada di dalam kelas masing-masing sebelum ustadz datang ke kelas.

Nilai kedisiplinan ini diterapkan bertujuan untuk membentuk karakter kedisiplinan santri (mahasiswa) terutama disiplin terhadap waktu dan disiplin terhadap diri sendiri. Seorang yang telah disiplin dalam menghargai waktu, menghargai diri sendiri dan orang lain. Kalau seseorang sudah terbiasa dalam menghargai sesuatu maka akan timbul rasa untuk selalu bersyukur dalam dirinya.

c. Nilai musyawarah

Pengaktualisasian nilai musyawarah dilaksanakan dalam proses belajar mengajar berlangsung. Yang mana ketika pembelaran di mulai dilakukan dengan cara berdiskusi tentang pelajaran yang akan di bahas. Pembahasan pelajaran ini dilakukan secara berkelompok 2 orang. Pembagian kelompok ini dilakukan 3 hari sebelum diskusi pelajaran di mulai. Ketika 2 orang menjelaskan pembelajaran, santri (mahasiswa) yang lain mendengarkan dan mencatat 
inti-inti dari pemaparan 2 0rang tersebut. Setelah selesai pemaparan, maka di mulailah proses Tanya jawab dan diskusi pemahaman terhadap masalah yang dipaparkan dan semua santri (mahasiswa) harus mengeluarkan pendapat. Dalam prosesnya ustadz berlaku sebagai penengah diskusi diantara para santri (mahasiswa) tersebut.

Tujuan diterapkan nilai musyawarah ini di dalam proses pembelajaran adalah agar para santri (mahasiawa) terbiasa bermusyawarah dalam menyelesaikan suatu masalah, selain itu dengan bermusyawarah di harapkan menghasilkan pribadi-pribadi yang selalu menghargai dan menghormati pendapat orang lain.

2. Dalam Kegiatan Keseharian

Nilai-nilai Islam yang diaktualisasikan Dalam kegiatan keseharian atau di luar kegiatan pembelajaran adalah nilai ubudiyyah, nilai kesederhanaan, nilai kejujuran

a. Nilai Ubudiyyah

Pengaktualisasian nilai ubudiyah di pondok pesantren Nurul Ummah diadakan dengan sholat berjamaah. Semua santri wajib melakukan sholat secara berjamaah baik itu santri yang berstatus mahasiswa maupun yang berstatus siswa. Dalam pelaksanaanya ketika azan sudah berkumandang maka semua santri wajib bergegas pergi ke masjid yang ada di pondok pesantren Nurul Ummah. Dalam pengecekannya dilakukan oleh para pengurus pondok pesantren dari bagian keamanaan. Hal ini dilakukan agar para santri tidak ada yang membolos dalam melakukan sholat berjamaah.

Dalam kegiatan sholat berjamaah terdapat asas kesetaraan. Tidak ada yang merasa lebih mulia satu sama lain, yang kaya atau miskin semuanya sama, yang membedakan diantara sesama manusia adalah ketaqwaan. Oleh karena itu melalui kegiatan rutinitas sholat berjamaah ini diharapkan dapat membentuk karakter religius santri (mahasiswa).

b. Nilai Kesederhanaan

Penerapan nilai kesederhanaan di pondok pesantren Nurul Ummah dilakukan dengan cara memberikan pasilitas seadanya kepada para santri (mahasiswa) seperti penyediaan tempat tidur yang hanya berada dilantai beralaskan karpet, penyediaan makanan seadanya di kantin Pondok pesantren. Pada intinya tidak ada pasilitas yang bersipat mewah yang dikhususkan kepada para santri (mahasiswa). Dengan menerapkan keserhanaah dalam keseharian santri (mahasiswa) sehingga santri (mahasiswa) terbiasa dengan kesederhanaan.

c. Nilai kejujuran

Pengaktulisasikan nilai kejujuran di pondok pesantren Nurul Ummah dilakukan dengan cara diadakannya kantin kejujuran. Di kantin pondok pesantren Nurul Ummah setiap santri (mahasiswa) melayani diri sendiri dalam mengambil makanan baik berupa nasi, lauk pauk, dan makanan-makanan lainnya tampa ada yang mengawasi. Pembayarannya dilakukan oleh santri (mahasiswa) sendiri dengan mengatakan jenis makan dan jumlah makanan tersebut kepada petugasnya. Diharapkan dengan cara ini, dapat membentuk karakter jujur dalam diri santri (mahasiswa). Ini dilakukan untuk mengajarkan mereka untuk jujur terhadap diri sendiri dan jujur terhadap orang lain. Kejujuran di zaman sekarang merupakan sesuatu yang mahal dan langka.

pembentukan karakter santri (mahasiswa) dipondok pesantren ini lebih menitik beratkan kepada metode pelatihan dan pembiasaan. Dengan melihat pengaktualisasian nilai-nilai Islam dalam kegiatan sehari-hari yang diterapkan, jelas terlihat melatih diri mahasiswa terbiasa dengan hal-hal yang diterapkan dalam keseharian secara berulang-ulang, sehingga apa yang diterapkan itu menjadi sebuah kebiasaan dalam kehidupan pribadi santri (mahasiswa). Kebiasaan inilah yang kemudian menjadi sebuah karakter yang terbentuk ke dalam diri santri (mahasiswa).

Pola yang dikembangkan dalam pelatihan dipondok pesantren Nurul Ummah ini menggunakan prinsip keduanya, yaitu prinsip penanaman nilai, partisipasi masalah dan mengembangkan kedirian. Hal tersebut terlihat dalam setiap kegiatan dalam mendidik dan membina mahasiswa yang studi di pondok pesantren ini.

Pemberian materi yang berbeda pada setiap jenjang selain untuk menambah wawasan dan pemahaman keagamaan para santri (mahasiswa), juga diharapkan dapat menumbuhkan kembang nilai-nilai Islam yang tersimpan dalam materi-materi agama yang bersumber dari kitab-kitab klasik (kitab kuning). Semua materi yang diajarkan di pondok pesantren Nurul ummah berasal dari kitabkitab kuning yang merupakan salah satu ciri khas dari lembaga pendidikan pesantren. 
Pengaktualisasian nilai-nilai Islam dalam membentuk karakter santri (mahasiswa) membutuhkan materi yang tepat terutama materi-materi yang bersumber dari ajaran-ajaran Islam itu sendiri. Pemahaman terhadap materi-materi keislaman memunculkan kesadaran akan pentingnya nilai-nilai yang ada di dalam materi tersebut. Sehingga dengan menyadari nilai-nilai Islam yang terkandung dalam setiap materi-materi keislaman tersebut dapat menuntun dan mengarahkan santri (mahasiswa) kepada pembentukan karakter yang lebih baik.

Dalam mengaktualisasikan nilai-nilai keislaman sehingga membentuk santri (mahasiswa), tidak cukup hanya melakukan pembinaan dalam kegiatan keseharian saja, tetapi juga membutuhkan kegiatan tambahan yang sudah terprogram oleh pondok pesantren. Adapun program-program tersebut yakni sebagai berikut:

\section{Program Mingguan}

Kegiatan Mingguan ini meliputi kegiatan yang diadakan oleh Asrama, Madrasah Diniyyah maupun Lembaga yang ada di Pondok Pesantren Nurul Ummah, diantaranya:

a. Maulid Barzanji, Dziba'I, Burdah, Sholat Tasbih

Kegiatan ini yang mengelola adalah pihak Asrama baik Mahasiswa dan Takhassus serta Pelajar. Kegiatan ini dilaksanakan setiap malam Jum'at. Pembentukan karakter santri (mahasiswa) tidaklah cukup dengan mengadakan ritual ibadah sholat fardhu saja, namun juga harus ditambah dengan kegiatan kegamaan lainnya. Ritual keagamaan merupakan ciri khas pendidikan pondok pesantren. Inilah yang membedakan antara pendidikan pondok pesantren dengan pendidikan lainnya. Tradisi keislaman pondok pesantren yang terus diterapkan dari generasi ke generasi membeuat pondok pesantren tetap eksis dalam dunia pendidikan.

b. Pengajian Ahad Pagi

Penyelenggaraan kegiatan ini selain untuk meningkatkan hubungan pondok pesantren dengan masyarakat sekitar, juga sebagai bentuk pengaktualisasian nilai-nilai Islam yang bersifat nilai sosial. Dalam Islam terdapat dua aspek yang sangat ditekankan yakni hubungan dengan Allah (hablum minallah) dan hubungan dengan sesama (hablum minannas). Oleh karenanya dengan melibatkan masyarakat di dalam pondok pesantren diharapkan dapat membentuk karakter sosial dan peduli terhadap sesama di dalam diri para santri (mahasiswa).

c. Program Bulanan

Selain kegiatan yang bersifat mingguan, pondok pesantren Nurul Ummah mempunyai program bulanan yang bersifat sebagai penunjang dan pendukung kualitas santri secara individu. Kegiatan tersebut antar lain:

a. Sema'an Al-qur'an

Sema'an Alqur'an ini terbagi menjadi dua yaitu semaa'an Alqur'an Komplek dan sema'an Alqur'an JQH.

1) Sema'an Qur'an Komplek diadakan setiap hari Kamis malam setiap bulan. Sema'an ini termasuk dalam kegiatan mandiri komplek yang dikelola oleh bagian Pengembangan Sumber Daya Manusia (PSDM) pondok pesantren Nurul Ummah.

2) Sema'an Qur'an JQH, merupakan sema'an Qur'an yang dikelola oleh anggota Jama'ah Qurra' wal Huffadz yang dilaksanakan di masjid Al Faruq pondok pesantren Nurul Ummah. Sema'an ini dilaksanakan sebagai media silaturrahim dengan para alumni disekitar pondok serta sebagai penunjang hafalan individu. Kegiatan ini dilaksanakan sekali dalam sebulan.

Kegiatan sema'an Qur'an ini selain menjadi forum untuk menambah hubungan keakraban dengan para alumni, juga diharapkan dengan adanya kegiatan ini dapat menumbuhkan karakter santri (mahasiswa) agar selalu menjalin hubungan silaturahmi dengan sesama.

b. Pengajian Rutin Malam Selasa Wage

Kewibawaan seorang Kiyai menjadikan suasana pendidikan pondok pesantren bernuansa religius. Penghormatan seorang santri (mahasiswa) terhadap Karismatik seorang Kiyai menumbuhkan sikap ta'zim serta hormat di dalam diri seorang santri (mahasiswa). Oleh karena itu, Kiyai di dalam pendidikan pesantren mempunyai pengaruh yang sangat besar dalam mempengaruhi kepribadian dan karakter santri (mahasiswa). Dengan adanya kegiatan ini diharapkan tidak hanya untuk membentuk hubungan 
silaturrahmi antara seluruh santri (mahasiswa) dengan para ustadz tetapi juga untuk menumbuhkan karakter ta'zim (penghormatan) di dalam santri (mahasiswa) terhadap sesama.

c. Bahtsul Masail Forum Kajian A'la

Penyelenggaraan kegiatan ini merupakan salah satu bentuk pengaktualisasian dari nilai-nilai Islam yakni nilai kemandirian dan nilai musyawarah. Dalam kegiatan ini para santri mencari suatu permasalahan yang harus di pecahkan melalui jalan musyawarah guna untuk mendapatkan suatu jawaban atas permasalahan tersebut. Diharapkan dengan adanya pembelajaran yang berbasis pemenacahan masalah ini dapat membentuk karakter kemandirian di dalam diri para santri (mahasiswa) di dalam menyelesaikan suatu permasalahan yang terjadi.

Pendidikan yang terprogram di pondok pesantren senantiasa menggunakan pendidikan yang berpedoman pada penyelesaian masalah. Ini merupakan salah satu strategi yang selalu digunakan dalam mengembangkan pola pikir, membentuk kepribadian, meneguhkan jiwa, menempa kesabaran. Berbagai strategi yang digunakan oleh pondok pesantren dalam menghasilkan santri yang berkualitas.

d. Program Tahunan

a. Orientasi dan Pengenalan PP. Nurul Ummah (OP3NU)

Kegiatan ini selain untuk memperkenalkan tentang seluk beluk pesantren, juga sebagai media pengaktualisasian nilai-nilai Islam yakni nilai ta'aruf (pengenalan). Di dalam Islam diajarkan untuk saling kenal-mengenali satu sama lainnya. Kependidikan pesantren yang selalu menunjukan keterbukaan terhadap dunia luar terutama bagi yang ingin berkecimpung di dalamnya diadakan dengan kegiatan perkenalan terhadap pondok pesantren ini. Diharapkan dalam kegaiatan ini dapat membentuk karakter saling kenalmengenal dan saling memahami satu sama lainnya dari awal berada di pondok pesantren.

b. Peringatan Hari Besar Islam (PHBI)

Kegiatan ini adalah agenda dari takmir Masjid Al Faruq yang didukung oleh kepanitiaan yang dibentuk serta pengurus PPNU. Kegiatan ini meliputi Muharroman, Maulid Nabi Muhammad SAW serta Isro' Mi'roj Nabi Muhammad SAW. Selain kegiatan inti, kegiatan ini juga menjadi media shodaqoh untuk anak yatim piatu dan fakir miskin yang membutuhkan. Seluruh rangkaian kegiatan ini bertempat di Masjid Al Faruq PPNU. Dengan adanya kegiatan keislaman ini diharapkan dapat membentuk karakter santri (mahasiswa) yakni karakter kedermawaan. Shodaqah merupakan salah satu cara untuk membiasakn diri agar menjadi pribadi yang dermawan.

c. Program KKN

Penyelenggaraan program KKN di pondok pesantren merupakan upaya untuk melatih santri (mahasiswa) agar bisa berkecimpung dalam masyarakat dan mempraktekan keilmuan yang didapatkan selama nyantri di pondok pesantren Nurul Ummah. Sebuah proses pendidikan di sebuah lembaga pada akhirnya berujuan demi kemaslahatan bersama, salah satunya kemaslahatan dalam masyarakat. Seorang santri (mahasiswa) ketika telah menyelesaikan kuliah akan berkecimpung di masyarakat. Oleh karena itu, santri (mahasiswa) harus mengerti hal-hal yang diperlukan dalam masyarakat sehingga santri (mahasiswa) tersebut tidak hanya menyandang sebuah gelar tetapi bermanfaat dalam kehidupan masyarakat. Dengan adanya program KKN yang dilaksanakan di daerah-daerah yang membutuhkan seperti ini, mengajarkan santri (mahasiswa) bahwa di luar sana banyak orang-orang membutuhkan bantuan. Sehingga dengan KKN ini dapat membentuk karakter kepedulian santri (mahasiswa) terhadap orang lain, kerjasama, berani dan kepemimpinan.

d. Program Tahfiz

Diadakannya program tahfiz di pondok pesantren Nurul Ummah tidak hanya mencetak santri yang hafal ayat-ayat al-Quran, namun lebih dari itu dengan adanya program ini dapat mencetak pribadi-pribadi yang senantiasa menjalani kehidupan berdasarkan al-Qur'an. Pragram tahfiz ini bukanlah program wajib, namun ini diperutukkan bagi santri yang mau dan bersedia saja baik itu santri dari kalangan mahasiswa maupun dari kalangan siswa. Membentuk karakter tidak terlepas dari ajaranajaran Islam, sebab nilai-nilai yang terkandung di dalam Islam berasal dari al-Qur'an. Oleh karenanya, di dalam suatu pendidikan pentingnya memberikan suatu pembelajaran yang berkenaan dengan al-Qur'an seperti hapalan surah-surah al-Qur'an. Penghafalan al- 
Qur'an dengan menggunakan menggunakan tiga metode diatas, karena dalam menghafal ayat-ayat al-Qur'an membutuhkan suatu kesabaran yang tinggi dan harus sering melakukan pengulangan. Penggunaan ke tiga metode tersebut tidak hanya untuk membantu santri (mahasiswa) dalam menghafal al-Qur'an, akan tetapi diharapkan dengan menghafal al-Qur'an ini dapat membentuk karakter sabar dalam diri santri (mahasiswa).

e. Program Penulisan Penelitian

Dalam melengkapi sebuah pendidikan bagi mahasiswa di pondok pesantren Nurul Ummah, terdapat program penulisan penelitian setingkat dengan skripsi. Program ini dikhusukan bagi santri (mahasiswa) yang telah mengikuti pendidikan tingkat 2 ulya (tingkat akhir). Tujuan dari Program ini adalah melatih santri (mahasiswa) dalam membuat karya ilmiah, sehinggga santri (mahasiswa) tidak hanya cerdas secara ilmu pengetahuan namun cerdas juga dalam membeuat sebuah karya tulisan.

Pendidikan yang dilaksanakan oleh pondok pesantren merupakan suatu sistem pembentukan dan penanaman karakter religius kepada peserta didik yang meliputi komponen pengetahuan, kesadaran, dan tindakan untuk melaksanakan nilai-nilai Islam, baik yang berhubungan dengan Tuhan Yang Maha Esa, sesama manusia, maupun lingkungan, sehingga menjadi manusia yang paripurna (insan kamil). Hal tersebut sejalan dengan tujuan pendidikan Nasional yakni untuk mencerdasan kehidupan bangsa, mengembangkkan bangsa Indonesia seutuhnya, yaitu manusia yang beriman, bertaqwa terhadap tuhan yang maha esa, berbudi peerti luhur, memiliki pengethauan dan keterampilan, sehat jasmani dan rohani, berkepribadian yang mantap dan mandiri serta rasa tanggung jawab kemasyarakatan dan kebangsaan. Dalam rumusan tersebut terdapat nilai-nilai luhur berupa ketuhanan, kerohanian, kemanusiaan, kemasyarakatan, kepribadian, kebangsaan, pengetahuan dan keterampilan. Nilai-nilai itulah yang menjadi cita-cita pendidikan kita. Pendidikkan Nasional merupakan pendidikan yang berakar pada kebudayaan bangsa Indonesia, sementara mayoritas Masyarakat Indonesia adalah Beragama Islam. Oleh karenanya, pendidikkan Nasional tidak terlepas dari nilai-nilai keislaman itu sendiri. Ini berarti pentingnya menanamkan dan mengembangkan seperangkat nilai dalam diri seluruh peserta didik bagi peranannya di masa yang akan datang.

Sebuah lembaga pendidikan, dalam menjalankan sistem-sistem yang terkait dengan seluruh aspek yang ada di dalamnya tidak terlepas dari faktor-faktor yang mendukung dan faktor-faktor yang menghambatnya. Adapun faktor-faktor tersebut yakni sebagai berikut:

1. Faktor-Faktor Pendukung Pembentukan Karakter Mahasiswa

Adapun faktor yang mendukung pembentukan karakter mahasiswa di pondok pesantren Nurul Ummah adalah:

a. Sarana dan Prasarana Yang memadai

Dalam melakukan suatu aktifitas pendidikan terutama yang berhubungan dengan pemebntukan karakter religious peserta didik, tidak terlepas dari keadaan sarana dan prasarana yang memadai. Sebab sara dan pras sarana merupakan suatu kebutuhan yang tidak bisa di abaikan dalam memperoleh pendidikan yang memadai. Membentuk suatu karakter religious peserta didik membutuh dukungan sarana dan prasarana yang memadai juga seperti masjid, perpustakaan kitab-kitab agama, ruangan kelas yang nyaman, serta lingkungan yang bersuana Islami.

b. Ketatnya Pengawasan/Peraturan Pondok Pesantren

Pengawasan dalam kegiatan-kegiatan di pondok pesantren Nurul Ummah di lakukan oleh para pengurus dalam masing-masing bidang. Ada pun bidang-bidang kepengurusan tersebut sebgai berikut:

a) Departemen Pengembangan Sumber Daya Manusia (PSDM); yang menangani berbagai macam potensi santri yang terwadahi dalam Unit Kegiatan Santri (UKS). Selain UKS departemen ini juga menangani pengajian non diniyyah atau ma'hadiyyah yang dilaksanakan ba'da subuh dan ba'da isya'. Disamping itu departemen ini juga bertanggung jawab terhadap keberlangsungan kegiatan malam jum'at baik yang dilakukan perkomplek maupun di masjid.

b) Departemen Keamanan dan Ketertiban; yang bertanggung jawab dengan segala ketertiban dan keamanan pesantren. 
c) Departemen Perlengkapan, Sarana dan Prasarana; yang menangani pengadaan perlengkapan dan semua sarana dan prasarana yang dibutuhkan oleh pesantren.

d) Departemen Kebersihan dan Keindahan; menangani piket kebersihan sehari-hari dan hal-hal yang berkaitan dengan kebersihan.

e) Departemen Hubungan Masayarakat; menangani penyambutan tamu dan menjalin hubungan-hubungan dengan masyarakat luas.

2. Faktor-Faktor Penghambat Pembentukan Karakter Mahasiswa

a. Kekurangan Pengurus

Pengurus merupakan suatu yang sangat penting dalam sistem pendidikan pondok pesantren. Kekurangan pengurus merupakan penghambat dalam pelaksanaan kegiatankegiatan pondok pesantren.

b. Banyaknya Kegiatan Santri (Mahasiswa) Di luar Pondok Pesantren

Sebagai seorang mahasiswa yang kuliah sambil nyantri di pondok pesantren, banyak mahasiswa yang melakukan kegiatan-kegiatan diluar pondok seperti melakukan kegiatan organisasi. Hal ini menjadi penghambat kelancaran dalam pendidikan mahasiswa di pondok pesantren.

\section{B. Efektifitas Pengaktualisasian Nilai-Nilai Islam di Pondok Pesantren Nurul Ummah Kotagede Yogyakarta}

Efektivitas pengaktualisasian nilai-nilai Islam dalam membentuk karakter religious mahasiswa di pondok pesantren Nurul Ummah dapat diketahui dengan menggunakan tehnik penilaian. Adapun tehnik penilaian yang penulis gunakan adalah observasi, penilaian ustadzustadz, serta analisis data lapangan. Penilaian tersebut dinyatakan dalam kualitatif sebagai berikut:

Tabel 1. Penilaian Karakter

\begin{tabular}{|c|c|c|}
\hline & BT (Belum Terlihat) & $\begin{array}{l}\text { Nilai ini diberikan apabila peserta didik belum } \\
\text { memperlihatkan tanda-tanda awal prilaku/karakter } \\
\text { yang dinyatakan dalam indikator. }\end{array}$ \\
\hline 2 & MT (Mulai Terlihat) & $\begin{array}{l}\text { Nilai ini diberikan kepada peserta didik sudah mulai } \\
\text { memeprlihatkan adanya tanda-tanda awal } \\
\text { prilaku/karakter yang dinyatakan dalam indikator. }\end{array}$ \\
\hline 3 & MB (Mulai Berkembang) & $\begin{array}{l}\text { Nilai ini diberikan kepada peserta didik yang sudah } \\
\text { memperlihatkan berbagai tanda prilaku/karakter yang } \\
\text { dinyatakan dalam indikator dan mulai konsisten. }\end{array}$ \\
\hline 4 & MK (Membudaya) & $\begin{array}{l}\text { Nilai ini diberikan kepada peserta didik yang terus } \\
\text { menerus memperlihatkan prilaku/karakter yang } \\
\text { dinyatakan dalam indikator. }\end{array}$ \\
\hline
\end{tabular}

Adapun indikator penilaian efektifitas pengaktualisasian nilai-nilai Islam dalam pembentukan karakter mahasiswa di pondok pesantren Nurul Ummah kota Gede Yogyakarta dapat dilihat pada tabel berikut:

Tabel 2. Indikator efektifitas aktualisasi nilai

\begin{tabular}{llll}
\hline No & $\begin{array}{l}\text { Indikator efektifitas } \\
\text { pengaktualisasian nilai } \\
\text { Mengerjakan ibadah sholat }\end{array}$ & $\begin{array}{l}\text { Nilai islam yang } \\
\text { diaktualisasikan }\end{array}$ & Nilai ubudiyah \\
2 & $\begin{array}{l}\text { lima waktu dalam keseharian } \\
\text { Melaksanakan pembacaan al } \\
\text { asma ul husna dan doa } \\
\text { bersama sebelum }\end{array}$ & Nilai ketauhidan & Religius, taat, disiplin \\
pembelajaran di mulai & $\begin{array}{l}\text { Religius, kasih sayang, taat, } \\
\text { bertanggung jawab, } \\
\text { kepemimpinan }\end{array}$ \\
$\begin{array}{l}\text { tawassunakan doa dan } \\
\text { sebelum belajar }\end{array}$ & Nilai Religius & Religius \\
\hline
\end{tabular}




\begin{tabular}{|c|c|c|c|}
\hline 4 & $\begin{array}{l}\text { Melaksanakan kegiatan } \\
\text { pembelajaran tepat waktu }\end{array}$ & Nilai kedisiplinan & Disiplin, bertanggung jawab \\
\hline 5 & $\begin{array}{l}\text { Melaksanakan kegiatan } \\
\text { mujahadah setiap malam } \\
\text { jumat }\end{array}$ & Nilai ubudiyah & Religius \\
\hline 6 & $\begin{array}{l}\text { Membeli makanan di kantin } \\
\text { pondok }\end{array}$ & Nilai kejujuran & Jujur, tanggung jawab \\
\hline 7 & $\begin{array}{l}\text { Menggunakan pasilitas yang } \\
\text { telah disediakan pondok }\end{array}$ & Nilai kesederhanaan & Sederhana \\
\hline 8 & $\begin{array}{l}\text { Melaksanakan kegiatan } \\
\text { musyawarah dalam } \\
\text { pembelajaran }\end{array}$ & Nilai musyawarah & $\begin{array}{l}\text { Menghargai dan } \\
\text { menghormati }\end{array}$ \\
\hline 9 & $\begin{array}{l}\text { Melaksanakan kegiatan kkn } \\
\text { pondok }\end{array}$ & Nilai kepemimpinan & Kepemimpinan, social \\
\hline 10 & $\begin{array}{l}\text { Membuat karya tulis bagi } \\
\text { santri tingkat ulya }\end{array}$ & Nilai karya & Kreatif \\
\hline 11 & Melaksanakan kegiatan haul & Nilai ubudiyah & Religius, taat \\
\hline
\end{tabular}

Dari hasil pengamatan peneliti dilapangan, pengaktualisasian nilai-nilai Islam dalam membentuk karakter mahasiswa sangat efektif. Hal tersebut terlihat dalam pelaksanaan kegiatan-kegiatan serta peraturan-peraturan yang ada di pondok pesantren Nurul Ummah terus meningkat, seperti ketika pelaksanaan ibadah sholat berjamaah, ketika sudah masuk waktu sholat seluruh santri (mahasiswa) langsung pergi ke masjid yang ada di pondok pesantren untuk melakukan sholat berjamaah, tidak ada santri yang membolos berjamaah. Dalam hal berbelanja makanan di kantin, santri (mahasiswa) yang makan dikantin ketika akan membayarnya mengatakan kepada petugas kantin seperti jumlah makanan yang mereka makan. Selain itu, Dalam hal bermusyawarah, para santri (mahasiswa) aktif dalam mendiskusikan pelajaran dan senantiasa bermusyawarah dalam meyelesaikan permasalahan yang terjadi di pondok pesantren bersama dengan para pengurus. Dalam ketaatan dalam mengikuti pelajaran, para santri (mahasiswa) selalu hadir dalam mengikuti pelajaran di pondok baik kegiatan belajar pada malam hari yang dimulai setelah magrib maupun kegiatan belajar yang dimulai setelah subuh. Dalam hal kesederhanaan, para santri (mahasiswa) senantiasa menggunakan pasilitas yang disediakan oleh pihak pondok pesantren tanpa ada yang merasa kekurangan dan melakukan protes. Semuanya menunjukan ketaatan terhadap seluruh hal yang ada di pondok pesantren Nurul Ummah.

Selain itu, santri (mahasiswa) juga aktif dalam melakukan kegiatan mingguan meliputi maulid Barzanji, Dziba'I, Burdah, sholat Tasbih, musyawarah, pengajian ahad pagi. Kegiatan bulanan meliputi sema'an al-Qur'an, pengajian rutin malam selasa wage, bahtsul masail forum kajian a'la. Program tahunan meliputi orientasi dan pengenalan pondok pesantren Nurul Ummah, haul al-maghfurlah kh. Asyhari Marzuqi, kegiatan KKN santri (mahasiswa), penulisan karya tulis. Penilaian efektifitas pengaktualisasian nilai-nilai Islam dalam pemebentukan karakkter mahasiswa berdasarkan penilaian para ustadz di pondok pesantren Nurul Ummah Kota Gede Yogyakarta, Berdasarkan hasil wawancara dengan para ustadz bahwa pengaktualisasian nilai-nilai Islam tersebut sangat efektif dalam memebentuk karakkter mahasiswa.

Pendidikan mempunyai peran penting dalam mencerdaskan dan membangun karakter bangsa. Keberhasilan suatu bangsa tergantung bagaimana generasi yang akan melanjutkan bangsa tersebut. Sebuah lembaga pendidikan Islam seperti pondok pesantren mempunyai tanggung jawab yang besar dalam mendidik generasi bangsa tersebut agar dalam prosesnya menghasilkan lulusan yang bermutu baik dalam ilmu pengetahuan maupun dalam kepribadian. Hakekat sebuah pendidikan tidak hanya mentransfer ilmu pengetahuan saja, namun lebih dari itu pendidikan juga membentuk manusia yang berkarakter.

Suatu pendidikan dikatakan berhasil apabila pendidikan tersebut banyak menghasilkan lulusan yang unggul dalam segala aspek. Keberhasilan dalam pendidikan akan membawa pengaruh yang besar dalam kehidupan lapisan masyarakat. Peserta didik yang telah memperoleh pendidikan yang tinggi akan kembali berkecimpung dalam kehidupan masyarakat. Oleh karena itu, pribadi-pribadi unggulan yang merupakan lulusan dari suatu lembaga pendidikan khususnya lembaga pendidikan Islam seperti pondok pesantren dalam mengubah pola pikir dan pola hidup masyarakat tersebut. 


\section{Kesimpulan}

Dalam proses pembentukan karakter mahasiswa di pondok pesantren Nurul Ummah Yogyakarta terlihat dalam proses perencanaan dan pelaksanaannya. Secara pelaksanaannya, jenjang pendidikan bagi mahasiswa di pondok pesantren Nurul Ummah trebagi menjadi tiga tingkatan yakni awwaliyyah, wustha, dan ulya. Pengaktualisasian nilai-nilai Islam di pondok pesantren Nurul Ummah di bagi ke dalam beberapa program yang meliputi: program harian, program mingguan, program bulanan, dan program tahunan. nilainilai Islam yang diaktualisasikan adalah nilai Illahiyah meliputi: nilai ubbudiyah dan nilai ketauhidan. Sedangan nilai yang bersifat insaniah meliputi: nilai kedisiplinan, nilai kesederhanaan, nilai kejujuran, nilai musyawarah. Kemudian proses pengaktualisasiaannya diterapkan dalam kegiatan pembelajaran dan kegiatan keseharian. Adapun pengaktualisasiannya dalam proses pembelajaran yakni sebagai berikut: pertama, nilai ketauhidan. Nilai ketauhidan ini dilakukan sebelum kegiatan belajar megajar berlangsung. Hal tersebut dilakukan dengan cara: setiap santri (mahasiswa) berkumpul di depan kelas masing-masing, kemudian membacakan al asmaul husna dan ditutup dengan doa bersama. Kedua, nilai kedisplinan. Nilai kedisiplinan ini dilakukan dengan cara: diberlakukannya peraturan bahwa semua santri (mahasiswa) sebelum pembelajaran di mulai sudah berada di dalam kelas masing-masing sebelaum ustadz datang ke kelas. Ketiga, nilai musyawarah. Nilai musyawarah dilakukan dengan cara berdiskusi tentang pelajaran yang akan di bahas. Pembahasan pelajaran ini dilakukan secara berkelompok. Keempat, nilai ubudiyah. Nilai ubudiyah ini dilakukan dengan cara sholat berjamaah, wirit dan pembacaan al-Qur'an setelah sholat berjamaah. Kelima, nilai kesederhanaan. Nilai ini dilakukan dengan cara memberikan pasilitas seadanya kepada para santri (mahasiswa) seperti penyediaan tempat tidur yang beralaskan karpet, penyediaan makanan seadanya di kantin Pondok pesantren. Keenam, nilai kejujuran. Nilai ini dilakukan dengan cara diadakannya kantin kejujuran. Selain itu, di dukung oleh kegiatan tambahan yaitu kegiatan tahfiz Qur'an, kegiatan KKN, dan kegiatan karya penulisan. Faktor yang mendukung pembentukan karakter religius mahasiswa di pondok pesantren Nurul Ummah adalah: sarana dan prasarana yang memadai, ketatnya pengawasan/peraturan pondok pesantren. Adapun faktor penghambatnya adalah Kekurangan Pengurus dan banyaknya kegiatan mahasiswa di luar pondok pesantren seperti kegiatan organisasi kampus.

\section{Referensi}

A'la, A. (2006). Abd. A'la, Pembaharuan Pesantren (Yogyakarta: Pustaka Pesantren.

Ali, S., Abdussakir, \& In'am Esha, M. (2013). Paradigma pesantren: memperluas horizon kajian dan aksi. UIN Maliki Press.

Hamid, H. S. (2010). Pengembangan Pendidikan Budaya dan Karakter Bangsa. Jakarta: Kementrian Pendidikan Nasional.

Husin, S. A. (2005). Aktualisasi Nilai-Nilai Qur'ani. Jakarta: Ciputat Press.

Kasiram, M. (2010). Metodologi penelitian: Kualitatif-kuantitatif. Uin-Maliki Press.

Mas' ud, A., Ismail, S. M., Huda, N., \& Kholiq, A. (2002). Dinamika pesantren dan madrasah. Kerjasama Fakultas Tarbiyah, IAIN Walisongo dengan Pustaka Pelajar, Yogyakarta.

Nata, A. (2013). Akhlak Tasawuf dan Karakter Mulia. Jakarta: Rajawali.

Nizar, H. S. (2013). Sejarah Sosial dan Dinamika Intelektual Pendidikan Islam di Nusantara. Kencana.

Shihab, M. Q. (2007). Secercah cahaya ilahi: Hidup bersama al-quran. Mizan Pustaka.

Usman, F. P. (2010). Kajian Filosofis Pendidikan Nahdlatul Wathan (NW) di Lombok. Yogyakarta: Teras.

Wiyani, N. A. (2013). Bina karakter anak usia dini. Yogyakarta: Ar-Ruzz Media. 